\title{
Lumen
}

Selected Proceedings from the Canadian Society for Eighteenth-Century Studies

\section{Words in Memory of Jay Macpherson}

\section{John Baird}

Volume 33, 2014

URI : https://id.erudit.org/iderudit/1026570ar

DOI : https://doi.org/10.7202/1026570ar

Aller au sommaire du numéro

Éditeur(s)

Canadian Society for Eighteenth-Century Studies / Société canadienne d'étude du dix-huitième siècle

ISSN

1209-3696 (imprimé)

1927-8284 (numérique)

Découvrir la revue

Citer ce document

Baird, J. (2014). Words in Memory of Jay Macpherson. Lumen, 33, 151-152.

https://doi.org/10.7202/1026570ar d'utilisation que vous pouvez consulter en ligne.

https://apropos.erudit.org/fr/usagers/politique-dutilisation/ 


\section{Words in Memory of Jay Macpherson}

(Spoken at the Saturday evening banquet by John Baird.)

Running my eye over the list of 2011 Donors to CSECS in the Conference Program, I paused at the name of Jay Macpherson. Jay slipped quietly away from the world in March of this year, but I wished that her name had appeared in the operative part of the Program, and that she might have given us another of the investigations into late eighteenth-century Viennese Freemasonry that so enhanced our understanding and enjoyment of Mozart's last work for the theatre, The Magic Flute.

Jay was a staunch supporter of CSECS and came to meetings regularly. She enjoyed meeting old friends, and especially hearing what younger scholars had to say. In 1993, when the Society was unable to meet, Jay organized a colloquium for graduate students in Toronto so that at least some of the younger members could find an audience for their research.

Like The Magic Flute, like life itself, Jay could always surprise one. Her academic career was so much identified with the University of Toronto, and especially with Victoria College, that it was easy to suppose that she had always lived on Berryman Street. Not so; as a small girl she had survived the worst part of the London Blitz, and was then removed for several years to the relative safety of St. John's, Newfoundland. I well remember her delight in revisiting St. John's for the first time for the 1992 CSECS meeting, and then again for the 2010 meeting.

Yesterday I learned from the paper given by Paul Rice of Memorial something I had not known about Mozart. He was so impressed by the performance of a young castrato, Venanzio Rauzzini, in his early opera Lucio Silla that he wrote for him the motet Exultate, Jubilate. This 
sublimely beautiful composition was inspired, not by high religious fervour, but by one generous young musician's admiration for the professional skill of another. I think Jay would have understood and appreciated that, and it suggests a way to say goodbye to Jay Macpherson. Think of Mozart, think of Jay, and say "Exultate, Jubilate." 